\title{
Enrichment of Inorganic Ions with Increasing Atomic Weight in Aerosol, Rainwater and Snow in Comparison with Sea Water
}

\author{
By M. Komabayasi \\ Water Research Laboratory, Faculty of Science, \\ Nagoya University \\ (Manuscript received 15 December 1961)
}

\begin{abstract}
On the basis of observational data presented by Sugawara (1956), it is found that the inorganic chemical composition of maritime aerosol, rainwater and snow in Japan differ systemtically from that of the sea water in such a way that logarithm of the enrichment coefficient of ions has an increasing linear relation with logarithm of their atomic weights.

$\mathrm{Na}, \mathrm{Mg}, \mathrm{K}, \mathrm{Ca}, \mathrm{CO}_{3}, \mathrm{Sr}$ and $\mathrm{I}$ follow the present relation. $\mathrm{F}, \mathrm{Fe}, \mathrm{Al}$ and $\mathrm{SO}_{4}$ deviate markedly from it. $\mathrm{Cl}$ is of intermediate nature.

The chemical data for other regions of the world show that the similar relation seems to hold for rainwaters in the Atlantic Ocean and in coastal areas of the Europe, of the North American Continent and also of the Antarctica.

Discussions are made on possible physical mechanism and meteorological conditions necessary to make up the found empirical law. Some isotope fractionation mechanism like thermo-gravitational effect is suggested to be important for the ionic enrichment at the air-sea interface.
\end{abstract}

\section{Introduction}

Aerosol particles originated from the sea are known to have an important role in several phases with micro-physical processes in the formation of cloud and rain. The presence of sea salt particles with largest size called "giant nuclei" is considered to be necessary for the formation of raindrops in a warm cloud (Ludlam 1951, Woodcock 1952, Komabayasi 1957). Sea salt particles of medium size or less, called "large and small" nuclei respectively are considered to be important as ordinary condensation nuclei of cloud droplets. Some component salts of the sea water have been found to possess a moderate ability of ice nucleation in a laboratory test (Isono et al 1959).

Several direct and indirect evidences have

* Division of Physics of Atmosphere and Hydrosphere, Contribution No. 2 suggested that the chemical composition of maritime aerosol may be different from that of the sea water. Sugawara et al (1949), Koyama and Sugawara (1953) collected aerosol with spanned sheets of cotton gauze at several points succesively inwards from the seashore on an island and found that the chemical composition of collected aerosol varied successively. For an explanation of this fact they presented an idea of fractional separation of salt crystals from sea spray drops in a drying stage. Isono $(1957,1959)$ found in an electron micro-diffraction analysis of fog droplet nuclei that some nuclei showed the diffraction of $\mathrm{MgCl}_{2} \cdot 6 \mathrm{H}_{2} \mathrm{O}$ without showing that of $\mathrm{NaCl}$. He suggested that fractional separation of $\mathrm{MgCl}_{2}$ from $\mathrm{NaCl}$ might occur in the drying process of sea spray particles. It is widely known that chemical compositions of rainwater and snow are different from that of the sea water and the difference changes systematically with in- 
creasing distance from the coast inwards to the continental area (Miyake 1948, Sugawara et al 1949, Rossby and Egnér 1955, Gorham 1958, Junge and Werby 1958, Eriksson 1960).

Laboratory experiments have been made to see whether the chemical composition of spray drops differs from that of mother liquid (Cauer 1951, Köhler and Båth 1952, Sugawara 1959). Also experiments have been made to study a production of many nuclei by the crystallization of spray drops. Recently Blanchard (1961) reviewed in detail the studies on theses secondary fractionation processes in his introductory remarks to the study of electrification of spray drops.

In the present article, an empirical law is presented concerning the concentration of inorganic ions contained in maritime aerosols, rainwater and snow. Chemical data of Japan, the Europe, the United States and the Ongle island of Lützow-Holm Bay of the Antarctica are used.

\section{Chemical composition of maritime aerosol}

In Fig. 1 the concentrations of inorganic ions in the aerosols analysed by Sugawara (1956) are illustrated against their atomic weights with logarithmic scales both in abscissa and ordinate. The concentration was expressed in a kind of relative concentration referenced to the sea water, the ratio of $\mathrm{M}_{1} / \mathrm{Cl}_{1}$ to $\mathrm{M}_{2} / \mathrm{Cl}_{2}$, where 1 refers to the ion concentration in the sample, and 2 refers

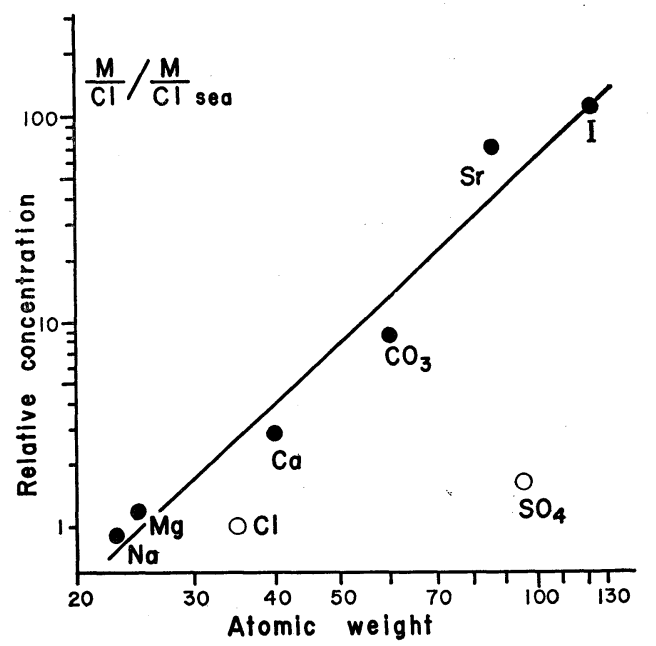

Fig. 1. Enrichment of ions in aerosol.

Sugashima Island (Top of the Island) to that of the sea water. This ratio is sometimes called enrichment coefficient. The sampling place was the top of Sugashima Island ( $200 \mathrm{~m}$ above sea level) on the Bay of Ise opening to the Pacific Ocean. A sampling device was a sheet of cotton gauze spanned against natural wind. Salts captured were dissolved in the distilled water and analysed. On the basis of calculation of capturing efficiency, it is considered that giant and large particles were captured by threads of gauze.

In Fig. 1, an approximate linear relation can be seen between the relative concentration and the atomic weight of ion for $\mathrm{Na}$; $\mathrm{Mg}, \mathrm{Ca}, \mathrm{CO}_{3}, \mathrm{Sr}$ and I. This shows that heavier ions had higher relative concentrations. On the other hand, $\mathrm{Cl}$ deviates a little and $\mathrm{SO}_{4}$ deviates markedly. A straight line best fitted is drawn for the sake of convenience of comparison. It was stated by Koyama and Sugawara (1953) that $\mathrm{CO}_{3}$ in this observation was total carbonic acid, but practically of carbonate, and that the amount of total cations were almost equal to that of total anions. This linear relation seen in Fig. 1 holds not only in the case of the data at the top of the island, but also in all cases of Sugawara's observation made in Sugashima Island at successively higher levels above the sea surface. (data illustrated in appendix). The higher is the level of sampling, the steeper the gradient of the best fitted straight line becomes. Based on these data, the approximate fall velocities of aerosol and henceforth the sizes of particles contributing mass distribution of each inorganic ion can be estimated if it is assumed that these aerosol particles are produced at the sea surface and dispersed in the atmosphere according to Fickian diffusion equation,

$$
\frac{\partial M_{i}}{\partial t}-\bar{V}_{i} \frac{\partial M_{i}}{\partial z}=D \frac{\partial^{2} M_{i}}{\partial z^{2}}
$$

where $M_{i}$ is the space density of a certain ion, $\bar{V}_{i}$ the average fall velocity of the corresponding particles, $D$ the coefficient of vertical diffusion, $t$ the time, $z$ the height above the sea surface. In a steady state, $\partial / \partial t=0$, the used relative concentration or enrichment coefficient can be expressed as 


$$
\begin{gathered}
\left(\frac{M_{i}}{\mathrm{Cl}}\right) /\left(\frac{M_{i}}{\mathrm{Cl}}\right)_{\text {sea }}=\frac{M_{i 0}}{\mathrm{Cl}}\left(\frac{M_{i}}{\mathrm{Cl}}\right)_{\text {sea }} \\
\cdot \exp \left(-\frac{\bar{V}_{i}-\bar{V}_{c l}}{D} z\right) .
\end{gathered}
$$

The suffix 0 means the value closely above the sea surface. In the present approximate estimation, the factor of the exponential term is regarded as unity, that is,

$$
\frac{M_{i 0}}{\mathrm{Cl}_{0}} \simeq\left(\frac{M_{i}}{\mathrm{Cl}}\right)_{\text {sea }} \text {. }
$$

This may be reasonable because the chemical composition of aerosol captured near the sea level is much closer to that of the sea water as compared with that captured at higher level and because the laboratory experiments of spraying made by three authors (Table 1) show the degree of fractionation is confined almost within $20 \%$, not so large as compared with the field observation at Sugashima where the relative concentration reached 100 times of original sea water.

Table 1. Laboratory experiments on primary fractionation.

\begin{tabular}{ll|l|l}
\hline \multicolumn{2}{c|}{ author } & method & \multicolumn{1}{c}{ qualitative result } \\
\cline { 1 - 2 } Cauer & 1951 & spray & $\mathrm{K}>\mathrm{Mg}>\mathrm{Cl}$ \\
Köhler and Båth & 1952 & spray & $\mathrm{Mg}, \mathrm{Cl}>\mathrm{Na}$ \\
Sugawara & 1959 & bubbling & $\mathrm{I}>\mathrm{Mg}^{2}>\mathrm{SO}_{4}>\mathrm{Sr}, \mathrm{Ca}, \mathrm{Cl}>\mathrm{Na}$ \\
\hline
\end{tabular}

So, using the data obtained at $200 \mathrm{~m}$ level, (any level will do,) we can estimate the value of $-\left(V_{i}-\bar{V}_{c l}\right) / D$ tabulated in Table 2 . If it is assumed that every element does not increase in the amount with increasing height and at most absolute space concentration of
I is constant with height, $\bar{V}_{c l} / D=2.34 \times 10^{-4}$ $\mathrm{cm}^{-1}$ is obtained and all other fall velocities over $D$ are calculated. Again if the value of the coefficient of vertical diffusion is assumed, sizes $\bar{d}$ of aerosol contributing to mass of

\begin{tabular}{|c|c|c|c|c|c|c|c|}
\hline & \multirow{2}{*}{$\begin{array}{c}\text { enrichment } \\
(\mathrm{M} / \mathrm{Cl}) /(\mathrm{M} / \mathrm{Cl})_{\text {sea }}\end{array}$} & \multirow{2}{*}{$\begin{array}{c}10^{-4} \mathrm{~cm}^{-1} \\
-\left(\bar{V}-\bar{V}_{c l}\right) / D\end{array} \mid$} & \multirow{2}{*}{$\begin{array}{c}10^{-4} \mathrm{~cm}^{-1} \\
\bar{V} / D\end{array}$} & \multicolumn{2}{|c|}{$D=10^{4} \mathrm{~cm}^{2} \cdot \mathrm{sec}^{-1}$} & \multicolumn{2}{|c|}{$D=10^{3} \mathrm{~cm}^{2} \cdot \mathrm{sec}^{-1}$} \\
\hline & & & & $\bar{V}\left(\mathrm{~cm} \cdot \mathrm{sec}^{-1}\right)$ & $\bar{d}(\mu)$ & $\bar{V}\left(\mathrm{~cm} \cdot \mathrm{sec}^{-1}\right)$ & $\bar{d}(\mu)$ \\
\hline $\mathrm{Na}$ & 0.98 & -0.0104 & 2.35 & 2.35 & 9.9 & 0.235 & 3.13 \\
\hline $\mathrm{Mg}$ & 1.2 & 0.0910 & 2.25 & 2.25 & 9.7 & 0.225 & 3.06 \\
\hline $\mathrm{Cl}$ & 1 & 0 & 2.34 & 2.34 & 9.85 & 0.234 & 3.12 \\
\hline $\mathrm{Ca}$ & 2.85 & 0.524 & 1.82 & 1.82 & 8.7 & 0.182 & 2.75 \\
\hline $\mathrm{CO}_{3}$ & 8.5 & 1.07 & 1.27 & 1.27 & 7.3 & 0.127 & 2.30 \\
\hline $\mathrm{Sr}$ & 71 & 2.13 & 0.21 & 0.21 & 3.0 & 0.021 & 0.93 \\
\hline $\mathrm{SO}_{4}$ & 1.61 & 0.238 & 2.10 & 2.10 & 9.3 & 0.210 & 2.96 \\
\hline $\mathrm{I}$ & 107 & 2.34 & 0 & 0 & 0 & 0 & 0 \\
\hline
\end{tabular}
each ion can be obtained.

Table 2. Average fall velocity and size of aerosol.

The estimated sizes of particles must be regarded as coarse approximates because many assumptions are superposed. The fall velocity of aerosol thus obtained is an average value over the air column $200 \mathrm{~m}$ in thickness and over the wide range of size of particle containing the particular ion.
Probably the estimated sizes may be those of concentrated sea spray droplets in drying stage, and may correspond to neither complete dried crystal nor complete sea spray. Inspite of many assumptions repeatedly superposed it could be considered at least that sea salt particles with size of giant or larger part of 
large nuclei might have mainly contributed to the fractionation of inorganic ions over that island. The particles corresponding to mass of different ions are not so largely different in size and may belong to the same class under the conventional classification with respect to size. Only iodide (including iodate) may be concentrated on much smaller nuclei or may be in a state of gas phase of free iodine because its fall velocity is much smaller than that of others. Terada (1959) who found a method of micro-analysis of iodide and iodate and applied it for geochemical study suggested that evaporation of iodine from the sea surface and from the salts once deposited to the ground surface by precipitation may contribute to the high concentration of iodide in the atmosphere. But in whatever size the main mass of iodide may be concentrated, the particles must finally have a size large enough to be collected on the thread of cellulose of gauze.

\section{Chemical composition of rainwater and snow}

In Figs. 2, 3 and 4, the concentrations of each ion in rainwater and snow are plotted against the atomic weight. Abscissa and ordinates are the same as Fig. 1. The linear relation between the relative concentra-

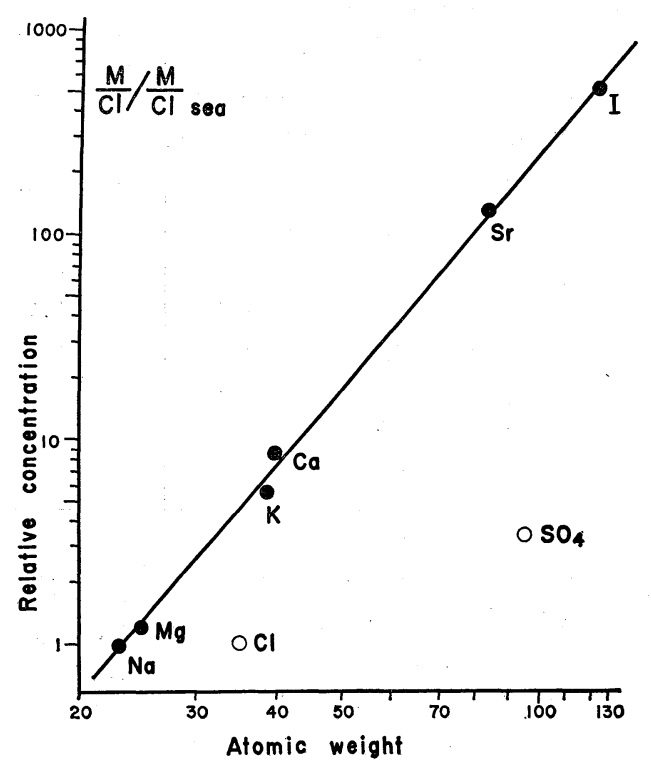

Fig. 2. Enrïchment of ions in rainwater. Sugashima Island (Pacific coast) tion and the atomic weight holds well for rainwaters except $\mathrm{Cl}$ and $\mathrm{SO}_{4}$ at Sugashima Island in the Pacific Ocean and at Kanazawa near the coast to the Sea of Japan. The plotted values are the average of the relative concentration of many samples. In the case of individual rainwaters, the concentration of each ion took a different value from the average one. The variation of concentration with time and the variation from rain to rain were always found, but the variation was confined usually within a factor of 5 . Accordingly the relation between the relative concentration and the atomic weight for an individual rain can also be expressed approximately in a straight line in a bilogarithmic plane. Therefore the linear relation can not be considered as sensitive to the precipitation mechanism of individual cloud, but may reflect the more steady and climatological factors operating in global scale. At Nagoya where heavy industry is present the linear relation does not hold and $\mathrm{Ca}$ seems to be higher. But the tendency of higher concentration of heavier ions is still conserved. This is considered to show that the amount of ions analysed by Sugawara may not be affected much by industry. These ions may have different sources from $\mathrm{NH}_{4}$ and $\mathrm{NO}_{3}$.

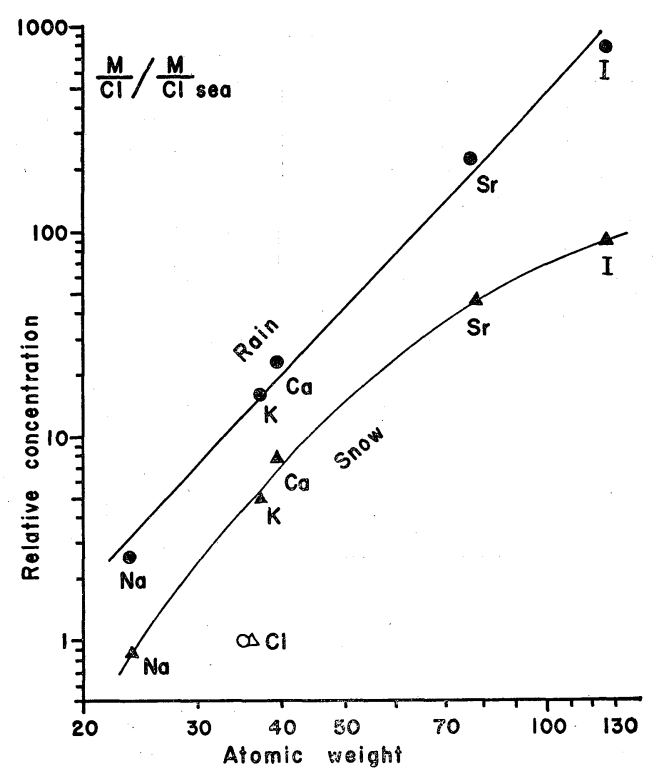

Fig. 3. Enrichment of ions in rainwater and snow.

Kanazawa (coast to the Sea of Japan) 


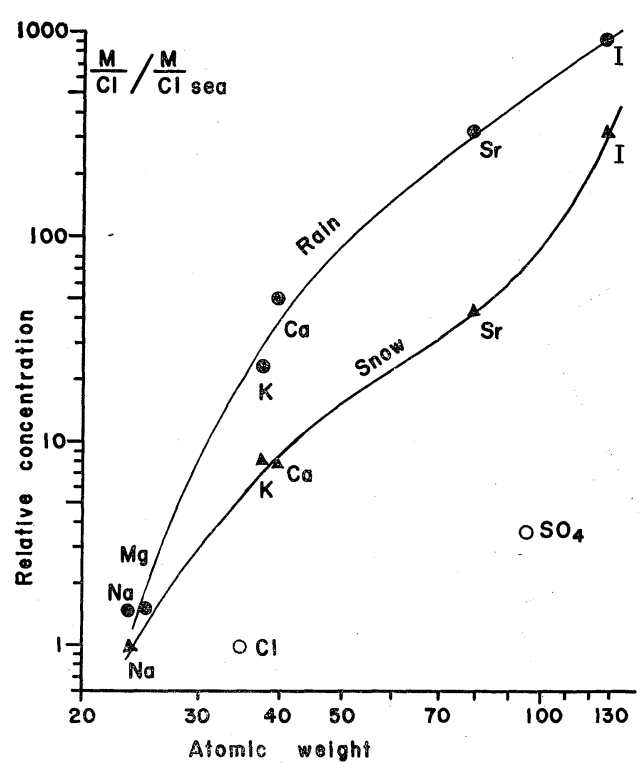

F1g. 4. Enrichment of ions in rainwater and snow.

Nagoya (heavy industry area)

In the case of snow, also heavier ions can be seen to have higher relative concentration, but a linear relation does not exist. The heavier ions are deficient as compared with rainwater. This means that the chemical composition of snow in Japan may be closer to that of the sea water than is that of rainwater. The absolute concentrations of $\mathrm{Na}$ and $\mathrm{Cl}$ in snow were higher than those in rainwater in Japan, while the absolute concentrations of $\mathrm{Sr}$ and $\mathrm{I}$ were lower than those in rainwater. It may be considered that snow crystals and flakes collect particles containing $\mathrm{Sr}$ and $\mathrm{I}$ with lower efficiency. Probably giant and large nuclei may be collected efficiently by a raindrop as a cloud droplets. Further, particles of smaller size may be collected by a raindrop if they are activated in condensation and form cloud droplets. On the other hand, direct collection of dry salt particles by a raindrop or snow flakes may occur with much less frequency because of hydrodynamical escape. If Langmuir's collision efficiency were adopted, particles smaller than 2 microns in radius could not collide with raindrops of any size. In snow cloud, the supercooled liquid water may be consumed rapidly by evaporation, thus particles containing $\mathrm{Sr}$ and $\mathrm{I}$, which are estimated in the previous section to be of smaller size than carriers of other elements, may be dried up and caught by snow flakes with lower efficiency. On the other hand, salt particles of largest size can form supercooled drops of drizzle by condensation and coagulation. These drizzle drops may collide with snow flakes and make rimed crystals adhered with supercooled droplets. Imai (1954) reported that snow which fell on the coast to the Sea of Japan (Station Wajima) usually consisted of ice crystals with many adhered frozen drops with hundreds microns in diameter. Largest particles of giant nuclei which are considered to consist of sea salt without fractionation may be thus contained in snow. This may lead to high absolute concentrations of $\mathrm{Na}$ and $\mathrm{Cl}$ in snow and make its chemical composition closer to that of the sea water. The ice forming nuclei of ice crystal falling on the coastal area of the Sea of Japan may be some clay minerals of semi-arid area of the Asian Continent (Isono et al 1959). Although these minerals must be contained in snow, their mass may be smaller than the whole mass of sea salt particles and can not be expected to increase $\mathrm{Ca}$ in snow with very high amount in average.

On the basis of the facts above mentioned it may be stated that at least in Japan $\mathrm{Na}$, $\mathrm{Mg}, \mathrm{K}, \mathrm{Ca}, \mathrm{CO}_{3}, \mathrm{Sr}$ and $\mathrm{I}$ are enriched in rainwater and in aerosol as compared with the sea water in such a way that heavier ions have higher relative concentration and the atomic weight of ion has a linear relation with the relative concentration in logarithmic expressions. $\mathrm{SO}_{4}$ deviates much from that relation. Before discussing the mechanism of constituting that relation we proceed to see whether the linear relation holds for another region of the world.

The extensive analysis of Junge and Werby (1958), and Eriksson (1959, 1960) include much data of $\mathrm{Na}, \mathrm{Mg}, \mathrm{Cl}, \mathrm{K}, \mathrm{Ca}$ and $\mathrm{SO}_{4}$ in precipitation whole over the United States, the Europe and some in the Atlantic area, though data of Sr and I are not included. Sugawara (1959) presented the content of $\mathrm{Na}, \mathrm{Mg}, \mathrm{Cl}$, $\mathrm{Ca}, \mathrm{Sr}, \mathrm{SO}_{4}$ and $\mathrm{I}$ in pool waters on the Ongle Island of Lützow-Holm Bay of the Antarctica where Japanese observation base "Showa" has been set up. These data may be con- 


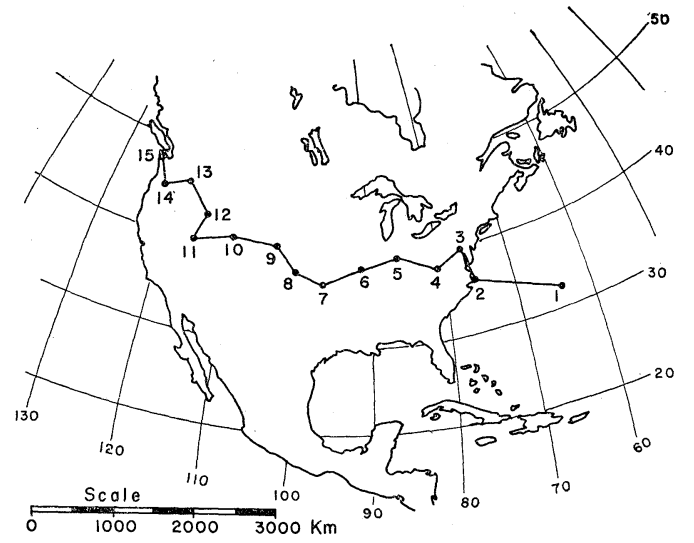

Fig. 5. North American stations where the relation is tested.

sidered to be available to some extent to determine whether the linear relation holds or not. In Figs. 5 and 6 , the sampling stations investigated in the present work are illustrated. As a matter of fact, at almost all the stations heavier ions except $\mathrm{SO}_{4}$ are found to have higher relative concentrations. But in the inland area the gradient versus atomic weight is very steep and it is unsafe to conclude that the linear relation would hold even if Sr and I were included. Very high gradient in the range of atomic weight between $\mathrm{Na}$ and $\mathrm{Ca}$ is a character of continental substance (see Fig. 8). Here we show the stations where the best fitted curve for $\mathrm{Na}, \mathrm{Mg}, \mathrm{K}$ and $\mathrm{Ca}$ is confined in the range of dispersion of the data of Japan area, where $\mathrm{Sr}$ and I are analysed. In these stations it might be inferred that the similar relation like the straight line for Japan area occurs. In the North America, the precipitation at stations $1,2,3$, and 4 in the east coast and the stations 14 and 15 in the west coast are found to satisfy the relation. In other stations, central and mountainous area, the gradient of the relative concentration versus atomic weight is too steep. In the Europe area, the precipitation at the stations $8,9,10$, and 14 , over whole British Ires ; stations $1,2,3,4,5,6$, and 7 , the coast of France 15 and 16 seem to satisfy the relation. In other area, the gradient of the curve is too steep.

In Fig. 7, the relative concentration of the

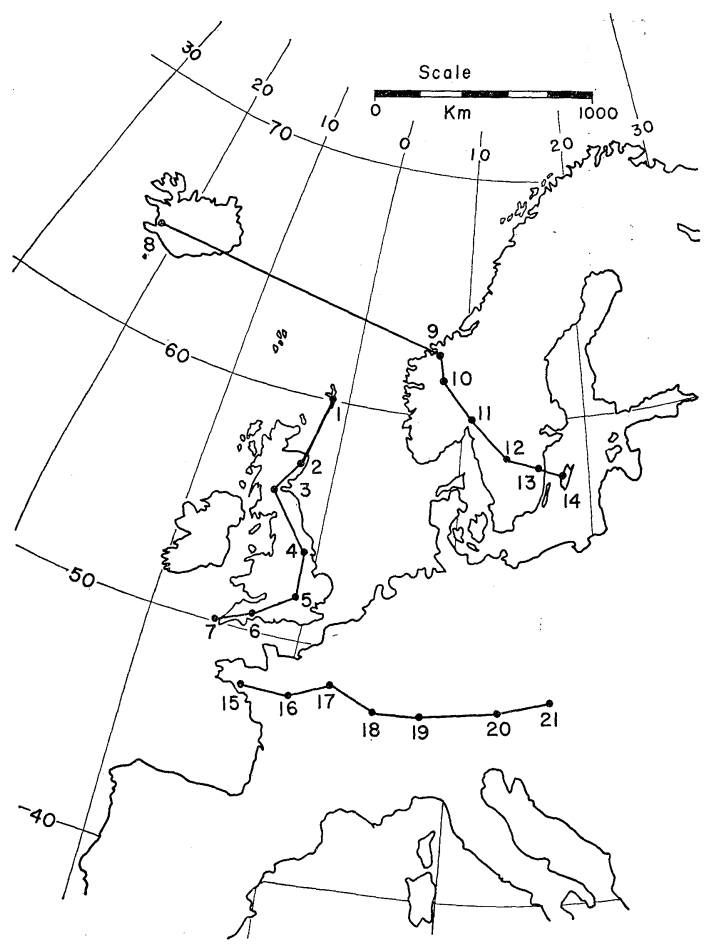

Fig- 6. European stations where the relation is tested.

pool water (average of three pool waters) presented by Sugawara (1959) is illustrated. Sugawara considered that sea spray particles originating from the near sea surface came to the pool water by the wind and resulted in the high absolute concentration of salts in the pool water. He attributed the difference between the chemical composition of the sea water and that of the pool water to the fractionation of chemical components in sea spray particles. For the sake of reference, in the same figure the chemical composition of aerosol collected on a sheet of cotton gauze near the sea shore of Sugashima Island is shown. Both chemical compositions show the similar increasing tendency with increasing atomic weight. If the ions of the pool water are more or less originated from the sea spray as Sugawara considered, the sea spray aerosol in the Antarctic coast may be of similar chemical nature as that in Japan. As the concentration of aerosols from land origins and from the human activity may be considered as lowest in the Antarctica, it is 


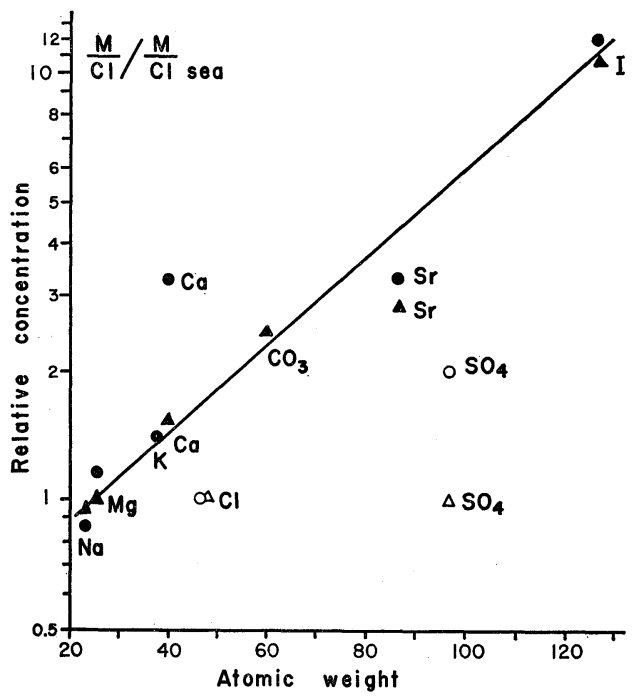

Fis. 7. Enrichment of ions in pool water in Antarctica. Ongle Island in Lützow-Holm Bay. The data of aerosol at Sugashima Island (seashore) are also shown. Circles show Antarctic, triangles Sugashima data.

expected that the difference of chemical compositions between sea spray and the sea water may take place without much presence of both land minerals and combustion product.

From the analysis made above, it may be concluded that in the oceanic and coastal area wide in the world the successively heavier ions of maritime origin are successively more concentrated relatively to the sea water in the aerosol and in rainwater, and that the relation between the enrichment coefficient and the atomic weight can be expressed in an increasing bilogarithmic linearity except $\mathrm{SO}_{4}$. Accordingly some mechanism which is strong and steady may be considered to operate continuously in the marine area under a wide variety of meteorological and oceanographic conditions.

The elements other than those shown in the foregoing figures were not analysed in the same samples. But if other data in Japan are used, general tendencies of $\mathrm{BO}_{3}, \mathrm{~F}, \mathrm{Al}$, $\mathrm{Fe}, \mathrm{SiO}_{3}, \mathrm{Cu}, \mathrm{Z}, \mathrm{V}$ and $\mathrm{Mo}$ in rainwater can be estimated (See, for instance, Sugawara 1956, Miyake and Sugiura 1957). Among these ions, $\mathrm{BO}_{3}$ (Mutoo 1952) in rainwater at Kiryu $110 \mathrm{~km}$ inland from the Pacific coast seems to follow approximately the linear relation stated. But other ions do not follow it. They are of much higher concentration. The reason that they are of higher concentration may be considered that they are nearly completely of land and industrial origin except $\mathrm{F}$. Concerning $\mathrm{F}$, the discussion is made in the last section.

\section{Situation where relation does not hold}

It may be important to note the area and the condition in which the stated relation between the enrichment and the atomic weight of ions does not hold. As shown above, inland area about $500 \mathrm{~km}$ or more distant from the coast is the place where the enrichment of $\mathrm{Ca}$ becomes very high.

Miyake and Sugiura (1954), showing the observation of Typhoons Kitty (31 Aug.-1 Sept. 1949) and Patricia (27-28 Oct. 1949), pointed out that $\mathrm{SO}_{4} / \mathrm{Cl}$ of the rainwater gradually decreased with approaching of the typhoon, became smaller than that of the sea water, and reached a minimum at the time of the closest approach of the typhoon center. The minimum values were at about $1 / 2$ of the value of the sea water. In Japan $\mathrm{SO}_{4} / \mathrm{Cl}$ of the rainwater is usually larger than the twofold of the sea water value, so this decrease found in typhoons may be highly significant and may be much concerned with the present problem. Discussion on this decrease is made later.

In the case of continental dust particles it may be considered that enrichments of $\mathrm{K}$ and $\mathrm{Ca}$ are much greater and the concentration of $\mathrm{Sr}$ and I are much smaller. Fig. 8 shows a kind of relative concentration of continental matter plotted against atomic weight. The figure shows the ratio of an element $(\mathrm{mg}$-atom $/ \mathrm{Kg}$ ) in continental matter to the element (mg-atom $/ \mathrm{Kg}$ sea water) in the sea. Clark Number is used as the continental abundance. In this case $\mathrm{Cl}$ is not used as a standard. It can be seen that the increase of the relative concentration against atomic weight is much steeper in the range including $\mathrm{Na}, \mathrm{Mg}, \mathrm{K}$ and $\mathrm{Ca}$, while a decrease appears in the range including $\mathrm{CO}_{3}, \mathrm{Sr}$ and I. When the influence of continental element is large in aerosol, the enrichment of $\mathrm{Sr}$ and I may become much smaller, or sometimes the deficiency will occur. Accordingly the successive enrichment from $\mathrm{Na}$ towards I 


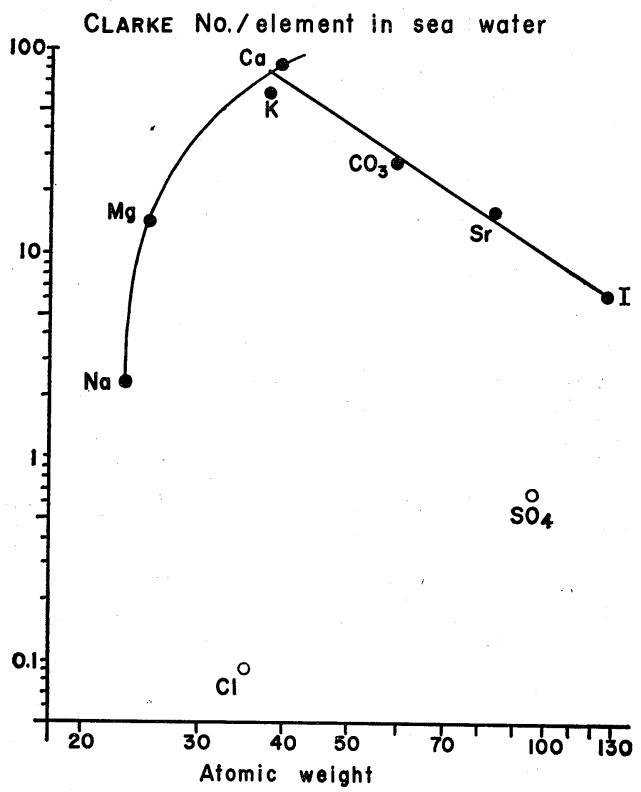

Fig. 8. Continental matter compared with sea water.

described in the foregoing sections is considered to be the nature of maritime aerosol. The reason that plotted points in Fig. 8 take a position in a smooth curve may be interesting problem concerning the origin of the ocean and the continent, but cannot be discussed in the present article.

The values of $\mathrm{Cl}$ and $\mathrm{SO}_{4}$ are again found to drop below the fitted curve in the same figure. This may show that $\mathrm{Cl}$ and $\mathrm{SO}_{4}$ are especially enriched much in the ocean.

There might be some possibility that combustion product provided all ions in comparatively equal amount and enrichment defined as the ratio to the sea water composition resulted in successively higher values because of successively lower absolute content of heavier ions in the sea with the exceptional values of $\mathrm{Cl}$ and $\mathrm{SO}_{4}$. Furthermore, some thermal diffusion process might enrich heavier ions more efficiently in fossil fuels in a long geological years. But the fact that the stated linear relation is found clearly in aerosol at the seashore where much amount of seasalt is present and also that the similar relation is found even in the Antarctic coast seems to support the idea that the relation found is not due to combustion product.

\section{Application of existing theories for ex- planation}

The mechanism of fractionation of chemical components at or near the sea surface has been discussed by many workers. But it is shown in this section that the found relation of enrichment to atomic weight of ions cannot be well explained by existing theories.

\section{Negative adsorption of ions at surface}

Negative adsorption of ions at the surface of aqueous solution was assigned for a mechanism giving rise to the difference of chemical composition between spray, foam film and the mother liquid (Cauer 1951, Facy 1951). In this case the order of enrichment should be a typical lyotropic series of electrolytic solutions for the surface tension and must have a close connection with the number of water molecules around ionized atoms in hydration. But this lyotropic series does not coincide with the order of the atomic weight. Also it cannot be considered that the negative adsorption alters much the chemical composition of spray drops with larger size than $0.1 \mu$. The reason is because Gibbs equation of adsorption shows the deficiency of salts at the surface is about $10^{-8} \mathrm{~g} / \mathrm{cm}^{2}$ in the case of sea water and this quantity corresponds to only $4 \%$ deficiency of the salt contained in a slab of sea water with $0.1 \mu$ thickness. So it may be difficult to attribute the observed high enrichment to the negative adsorption alone.

\section{Biological matter}

A selective entrainment of ions into biological matter (Wilson 1959, Jones 1960) and a selective adsorption of divalent cations to the biologidal products (Eriksson 1960) might be important in some region of the sea where the biological activity is high. But it seems difficult that the fractionation occurring nearly whole over the oceanic area uniformly from the northern hemisphere to the Antarctica is caused mainly by the biological activity.

\section{Electrophoretic motion in geomagnetic field}

An idea of separation of colloidal particles having electric charges by the electromotive 
force due to the movement of the sea water across the geomagnetic line of force was presented (Goldberg 1954) and critically discussed (Goldberg and Arrhenius 1959) concerning $\mathrm{Mn}$ deposit at the bottom of the deep sea. If this idea is applied to the ionic fractionation at the sea surface, the vertical velocity of the monovalent ions in the water may be microns per second. An induced electromotive force due to a sudden variation of the geomagnetic field also may have the effect of the same magnitude. But in these cases the order of separation should be that of the mobility of ions and also the enrichment should occur exclusively for the ions of the same sign. This order does not coincide with the order of the atomic weight.

\section{Fractional crystallization}

Sugawara et al (1949) and Koyama and Sugawara (1953) pointed out that the enrichment of ions was inversely parallel qualitatively with the solubility of their compounds and proposed the idea of the post fractionation. This means that crystals of $\mathrm{CaCO}_{3}, \mathrm{CaSO}_{4}$, and $\mathrm{MgCO}_{3}$ etc. are separated out from the brine drops during suspending in the air under the drying process. Generally speak ing, the heavier ions have less solubility. So it seems difficult to distinguish without experimental evidences the effect of atomic weight from the effect of solubility on the enrichment of ions in aerosol. But large difference of enrichment between $\mathrm{Ca}$ and $\mathrm{Sr}$ seems to support that the atomic weight affects the enrichment mechanism directly without through the solubility, because the solubilities of $\mathrm{CaCO}_{3}$ and $\mathrm{SrCO}_{3}$ are nearly of the same magnitude. Kitano and Kawasaki (1958) showed experimentally that $\mathrm{Sr}$ was entrapped in $\mathrm{CaCO}_{3}$ separated from the solution including $\mathrm{Ca}$ and a small amount of $\mathrm{Sr}$, the molar ratio $\mathrm{Sr} / \mathrm{Ca}$ in precipitate being 0.003 over a wide range of $\mathrm{Sr}$ concentration in the mother liquid. The molar ratio $\mathrm{Sr} / \mathrm{Ca}$ found in maritime aerosol sampled at Sugashima Island is 0.23 and much larger than the former.

Eriksson (1960) discussed against the fractional crystallization theory pointing that the separation of minute crystals from the brine drops seems unlikely to occur because the surface tension prevents their independent motions. Blanchard (1961) also discussed against both from the viewpoint similar to Eriksson' one and from the fact that experiments of drying sea water drops had not shown effective production of crystals except Twomey and McMaster's observation (1955). Indeed, the present author also considers it to be difficult that the fractional crystallization alone produces particles containing $\mathrm{K}$, $\mathrm{Ca}, \mathrm{CO}_{3}, \mathrm{Sr}$ and I of sufficient large size to be collected effectively on the threads of cotton gauze and on needles of pine trees. But the fundamental idea of that theory that different ions are concentrated in different particles should be considered to be conserved.

\section{Gas phase fractionation}

Cauer (1950), Rossby and Egner (1955) and Gorham (1958) pointed out the possibility for escape of $\mathrm{Cl}$ in a gaseous state from spray drops, aerosol and hail particles respectively. This process may contribute to the increase of $\mathrm{Na} / \mathrm{Cl}$, but could not explain the successively higher enrichment of successively heavier ions.

Gast and Thomson (1959) and Miyake and Kadokai (1961) presented the experiments showing the evaporation of $\mathrm{H}_{3} \mathrm{BO}_{3}$ and $\mathrm{I}_{2}$ from the sea water respectively. This process may be important for anions. But the enrichment of cations could not be explained. It is considered that a theory for the problem in the present article should not contradict the experimental evidences concerning evaporation of some anions.

\section{Synfractionation}

Sugawara (1959) presented a result of experiment in which violent bubblings of the sea water produce drops having a chemical composition in bulk different from that of the mother sea water (Table 1). He called this fact "synfractionation", but mechanisms contributing to the fractionation was not discussed clearly in his report.

This fractionation may be partly explained on the basis of the negative adsorption of ions at the water surface or at the foam film. But the present author, based on a different idea, tries in the following section to speculate 
a mechanism which results in enrichment of heavier ions in spray drops though the experimental evidence is not presented.

\section{Discussion on mechanism of observed enrichment}

The simple and distinct relation of the observed enrichment of ions to their atomic weights seems to show that a physical mechanism rather than chemical one may take place in the air-sea interface. Some isotope fractionation, a kind of thermal diffusion process may be considered as a possible mechanism. It is known theoretically and experimentally that heavier molecules are concentrated in the cool end and lighter ones in the warm end in a gas mixture under an appropriate condition of intermolecular force (for instance, Chapman and Cowling 1958). The similar facts have long been noticed in liquid mixtures and in electrolyte solutions as Ludwig-Soret effect (for instance, Agar 1959). Also it is known that thermo-gravitational separation in a Clusius-Dickel apparatus is much more rapid and effective, about which Hirota (1941, 1942, 1943) presented a series of experiments for aqueous solutions.

On the other hand, there may be a possibility that a steep vertical temperature gradient is formed at the surface of the sea or at the surface film of bubbles due to the loss of the heat by the evaporation and the long wave radiation. Under usual meteorological or climatological conditions where the wet bulb temperature of the air is several degrees lower than the temperature of the sea water, the expected temperature gradient may be such that the cool end is outside facing to the air and the inner part is warmer. Considering that the energy of the long wave radiation is nearly completely absorbed to $1 / 100$ by passing $20 \mu$ depth of water, the temperature gradient will be concentrated in a surface layer within $20 \mu$ depth. (Y. Takahashi (1960) pointed out the presence of such temperature gradient on the snow surface in the Antarctica.) If the heavier ions are proportionally enriched at the cool end, and the separation is sufficiently quick and strong, the found relation in question may be attributed to it. In this case it is considered that the order of enrichment may not always be that of thermal diffusion constant in the conventional pure Soret effect, because in the latter the complicated surface phenomena do not play a role. If the successively heavier ions are enriched in the cool surface with successively higher relative concentration and also if this enrichment receives a restricting condition that the electrical neutrality must be conserved approximately, a linear relation between logarithms of enrichment and atomic weight of ions may result with deviations of $\mathrm{SO}_{4}$, because the absolute concentration of $\mathrm{SO}_{4}$ is high. If $\mathrm{SO}_{4}$ were enriched in proportion to its atomic weight as other ions, the negative charge would become predominant at the surface layer of the sea.

The quantitative estimate of pure LudwigSoret effect shows that the difference of concentration is about a few percent for $10^{\circ} \mathrm{C}$ difference of the temperatures (possible maximum) at the both end of the temperature gradient in the sea water. This value is too low to explain the observed enrichment. Also pure Ludwig-Soret effect seems to be too slow to make up the enrichment in the actual sea surface.

There may be a possibility that the presence of many small bubbles would accelerate the separation. Blanchard and Woodcock (1957) showed that bubbles smaller than $100 \mu$ in diameter were abundant in the sea where white caps of waves had broken. Toba (1961) showed using a water channel with a wind tunnel that bubbles are distributed vertically in a decreasing exponential function with depth in number. If this collection of small bubbles move upwards or the water column enrichd in bubbles moves upwards with a slow velocity, the coupling of the thermal diffusion of ions with this systematic vertical flow might induce a stronger and quick separation of ions like thermo-gravitational effect, which might as well be called "thermofloatation" effect. If sea spray drops consist of the water of the surface layer, the smaller drops must represent higher enrichment of ions and its chemical composition may differ much from that of the sea water. The drops of larger size may have a composition closer to that of the sea. After drops are produced, gravitational settling in the atmosphere may change the size spectrum of drops, causing 
the fractionation to be higher degree as indicated in section 2 .

When the wet bulb temperature is higher than the temperature of the sea water, the direction of temperature gradient may become opposite, and the series of ions in enrichment may become inverse. When the violent tropical storm arrives at Japan in the temperate latitude, the wet and warm air comes from the south with a large velocity and the cloud base is low. In this condition, the temperature gradient at the sea surface may turn opposite. It may be suspected that the abnormal $\mathrm{SO}_{4} / \mathrm{Cl}$ value found by Miyake and Sugiura (1954) might represent this phenomenon. But there is another possibility in this case that the heavy continuous rain supplies the pure water onto the sea surface with a rate hundreds $\mathrm{mm} / \mathrm{hr}$. and $\mathrm{Cl}$ diffuses much faster than $\mathrm{SO}_{4}$ into this pure water layer, thus $\mathrm{Cl} / \mathrm{SO}_{4}$ becomes larger than usual because the rate of molecular diffusion of $\mathrm{Cl}$ is much larger than that of $\mathrm{SO}_{4}$. If this surface water becomes spray drops, $\mathrm{SO}_{4} / \mathrm{Cl}$ may become abnormally small. (The explanation made by Miyake and Sugiura (1954) is different from the both explanations mentioned above.)

Escape of gaseous iodine from the sea may be proportionally accelerated with enrichment of iodide in the surface layer. So high concentration of $I$ in the air or aerosol does not seem always to contradict with the present idea. The circumstances may be the same in the case of $\mathrm{H}_{3} \mathrm{BO}_{3}$.

The high enrichment of $\mathrm{F}$ seems to contradict the found empirical law between the enrichment and the atomic weight unless $F$ is mainly supplied from volcano, or sources other than the sea. But as fluoride ion is nearly of the same weight as the solvent water molecule, the law of thermal diffusion might become rather ${ }_{\mathrm{c}}$ complicated for $\mathrm{F}$. This might be one of the reason why $F$ deviates in behavier from other ions.

\section{Acknowledgement}

The author wishes to express his deep thanks to Prof. K. Isono, Prof. T. Koyama and Prof. K. Sugawara, Water Research Laboratory, Nagoya University, who critically discussed much about the present article and gave the author several useful suggestions.

The author also is grateful to Mrs. N. Kanamori who discussed in detail about the geochemical aspect of $\mathrm{Sr}$ and $\mathrm{Ca}$ concerning the present work and suggested many important problems.

\section{Appendix}

Numerical values $(\mathrm{M} / \mathrm{Cl}) /(\mathrm{M} / \mathrm{Cl})_{\text {sea }}$ used in the present work are tabulated as follows. Sampling points of Sugashima Island are referred to Fig. 1 of Koyama and Sugawara (1953).

\begin{tabular}{|c|c|c|c|c|c|c|c|c|c|c|c|}
\hline \multirow{2}{*}{ area } & \multirow{2}{*}{ sample } & \multirow{2}{*}{ place } & \multicolumn{8}{|c|}{ enrichment $(\mathrm{Cl}=1)$} & \multirow{2}{*}{ author } \\
\hline & & & $\mathrm{Na}$ & $\mathrm{Mg}$ & $\mathrm{K}$ & $\mathrm{Ca}$ & $\mathrm{CO}_{3}$ & $\mathrm{Sr}$ & $\mathrm{SO}_{4}$ & $\mathrm{I}$ & \\
\hline \multirow{6}{*}{$\begin{array}{c}\text { Japan } \\
\text { Sugashima }\end{array}$} & \multirow{6}{*}{ aerosol } & \multirow{6}{*}{$\begin{array}{l}2 \\
3 \\
4 \\
5 \\
6 \\
7\end{array}$} & 0.95 & 1.01 & - & 1.62 & 2.44 & 2.61 & 1.00 & 10.7 & \multirow{6}{*}{$\begin{array}{l}\text { Sugawara } \\
\text { et al (1949) } \\
\\
\text { Koyama } \\
\text { and } \\
\text { Sugawara } \\
\text { (1953) }\end{array}$} \\
\hline & & & 0.98 & 1.02 & - & 1.73 & 4.15 & 36.3 & 1.24 & 21.5 & \\
\hline & & & 1.00 & 1.07 & - & 1.90 & 5.16 & 40.3 & 1.32 & 22.8 & \\
\hline & & & 0.98 & 1.20 & - & 1.97 & 7.02 & 55.7 & 1.44 & 65.7 & \\
\hline & & & 0.98 & 1.21 & - & 2.85 & 8.46 & 71.0 & 1.61 & 107 & \\
\hline & & & 0.99 & 1.16 & - & 2.61 & - & 77.8 & 1.49 & 109 & \\
\hline Sugashima & rain & & 0.99 & 1.2 & 5.7 & 8.7 & \multicolumn{2}{|c|}{-133} & 3.5 & 500 & \multirow{3}{*}{$\begin{array}{c}\text { Sugawara } \\
(1956)\end{array}$} \\
\hline \multirow[t]{2}{*}{ Kanazawa } & rain & & 2.56 & - & 15.5 & 22.9 & \multicolumn{2}{|c|}{-216} & - & 785 & \\
\hline & snow & & 0.88 & - & 5.0 & 7.9 & & 46.7 & - & 85.7 & \\
\hline \multirow[t]{2}{*}{ Nagoya } & rain & & 1.51 & 1.49 & 23.3 & 50.00 & \multicolumn{2}{|c|}{-316} & 3.7 & 930 & \\
\hline & snow & & 0.99 & - & 8.3 & & \multicolumn{2}{|c|}{-43.4} & - & 330 & \\
\hline \multirow{2}{*}{$\begin{array}{l}\text { North } \\
\text { America }\end{array}$} & \multirow{2}{*}{$\begin{array}{l}\text { rain } \\
\text { and } \\
\text { snow }\end{array}$} & 1 & 1.06 & - & \multirow{2}{*}{$\begin{array}{l}1.46 \\
1.74\end{array}$} & 11.1 & \multirow{2}{*}{-} & \multirow{2}{*}{$\begin{array}{l}- \\
-\end{array}$} & 1.22 & - & \\
\hline & & 2 & 1.17 & - & & 3.04 & & & 1.88 & -1 & \\
\hline
\end{tabular}

Vol. 40, No. 1, 1962 


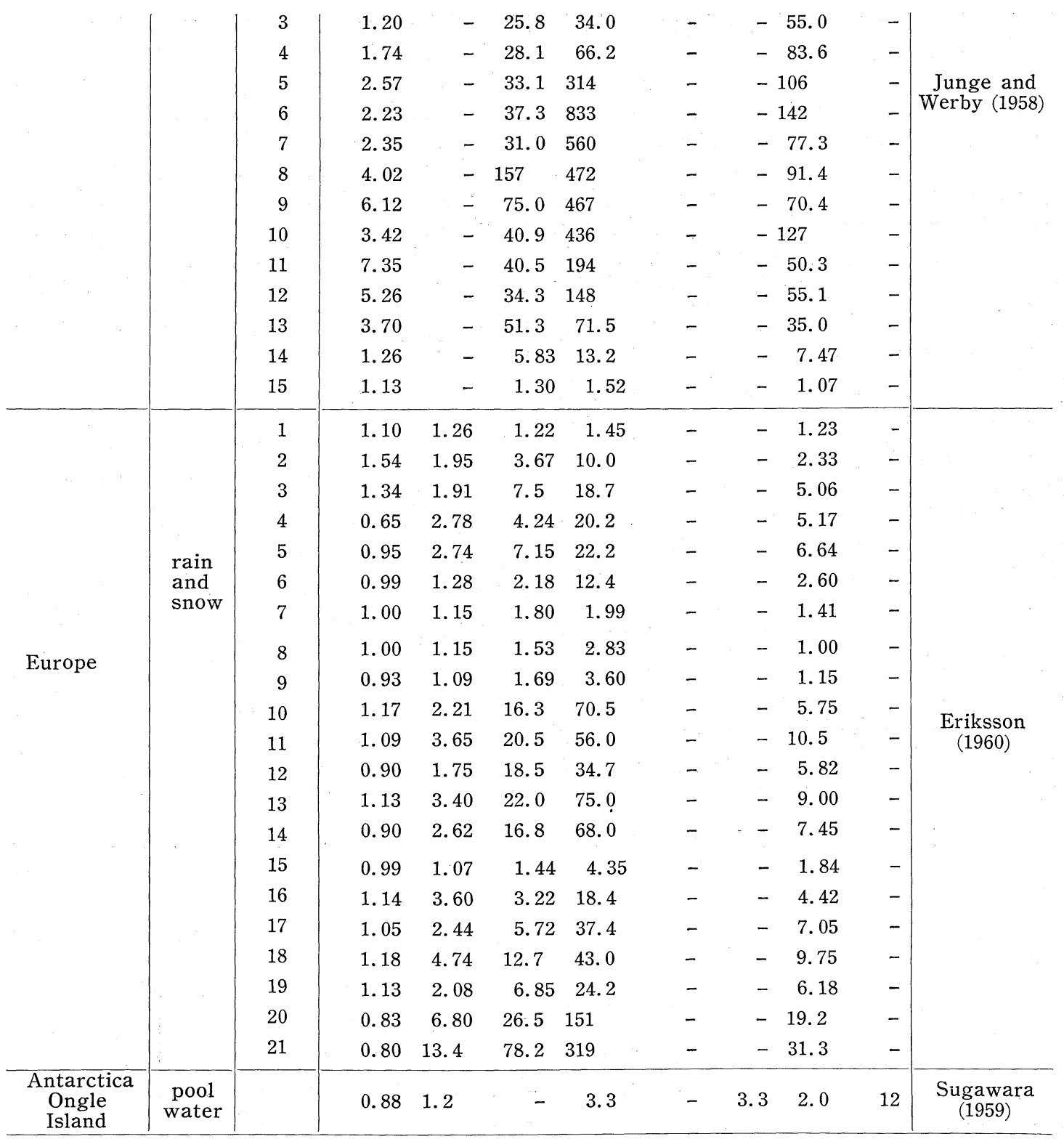

\section{References}

Agar, J.N. (1959) : Thermal diffusion and related effects in solutions of electrolytes. The Structures of Electrolytic Solutions. edited by Hamer W.J., John Wiley, New York, 200-223.

Blanchard, D.C. (1961): The electrification of the atmosphere by particles from bubbles in the sea. Unpublished Manuscript, Woods Hole Ocean. Inst. Tech. Rep. No. 61-9.

- and A.H. Woodcock (1957): Bubble formation and modification in the sea and its meteorological significance. Tellus, 9, 145-158.
Cauer, H. (1951): Some problems of atmospheric chemistry. Compendium of Met., Amer. Met. Soc., Boston, 1126-1136.

Chapman, S. and T.G. Cowling (1958): The Mathematical Theory of Non-Uniform Gases, 2 nd ed., Cambridge Univ. Press., Chap. 14.

Eriksson, E. (1959): The yearly circulation of chloride and sulfur in nature ; meteorological, geochemical and pedological implications, Part I, Tellus, 11, 375-403.

- (1960) : Part II. Ibid., 12, 63-109.

Facy, L. (1951) : Embruns et noyaux de condensation. J. Scientifiqué de la Météorologie, 3, 
62-68.

Gast, J.A. and T.G. Thompson (1959): Evaporation of boric acid from sea water. Tellus, 11, 344-347.

Goldberg, E.D. (1954) : Marine geochemistry 1. Chemical scavengers of the sea. J. Geol., 62, 249-265.

Goldberg, D.E. and G.O.S. Arrhenius (1958): Chemistry of Pacific pelagic sediments. geochim. Cosmochim. Acta, 13, 153-212.

Gorham, E. (1958) : The influence and importance of daily weather conditions in the supply of chloride, sulphate and other ions to fresh waters from atmospheric precipitaition. Proc. Roy. Soc., B, 241, 147-178.

Hirota, K. (1941): Studies on the thermal diffusion of solution I. On the measurement of the thermal diffusion constant. J. Chem. Soc. Japan, 62, 480-484.

(1942) : III. Thermal diffusion coefficient and Soret coefficient. Ibid., 63, 999-1006.

- (1943) : VI. On the thermal diffusion of solutions of mixed electrolytes. Ibid., 64, 112 -119 .

Imai, I. (1954) : A study of the monsoon snowfall at Wajima. J. Met. Soc. Japan, 32, 192-210.

Isono, K. (1957): On sea salt particles in the atmosphere. Geofis. pur. appli., 36, 156.

(1959): Microphysical processes in precipitation mechanism. Japan. J. Geophys., No. 2, 1-57.

$\longrightarrow$, M. Komabayasi and A. Ono (1959): The nature and the origin of ice nuclei in the atmosphere. J. Met. Soc. Japan, 37, 211-233.

Jones, E. (1960): Contribution of rainwater to the nutrient economy of soil in northern Nigeria. Nature, 188, 432.

Junge, C.E. and R.T. Werby (1958) : The concentration of chloride, sodium, potassium, calcium, and sulfate in rain water over the United States. J. Met., 15, 417-425.

Kitano, Y. and N. Kawasaki (1958): Behavior of strontium ion in the process of calcium carbonate separation from bicarbonate solution. J. Earth Sci. Nagoya Univ., 6, 63-74.

Köhler, H. and M. Båth (1952): Quantitative chemical analysis of condensation nuclei from sea water. Nova Acta Reg. Soc. Scient. Upsalienses $15: 7,24 \mathrm{pp}$.

Komabayasi, M. (1957) : Some aspects of rain formation in warm cloud (I). Salinity of individual raindrops and other quantities concerning rainfall. J. Met. Soc. Japan, 35, 205- . 220 .

(1957): (II) Liquid water content as a function of upward velocity. Ibid., 35, 266-277.

- (1959): Dissolved oxygen in rainwater and its relation to the raincloud structure (II). Precipitation from April to September. Ibid., 37, 35-41.

- and Y., Ikebe (1961): Organic ice nuclei : Ice-forming properties of some aromatic compounds. Ibid., 39, 82-95.

Koyama, T. and K. Sugawara (1953) : Separation of the components of atmospheric salt and their distribution (continued). Bull. Chem. Soc. Japan, 26, 123-126.

Langmuir, I. (1948) : The production of rain by a chain reaction in cumulus clouds at temperatures above freezing. J. Met., 5, 175-192.

Ludlam, F.H. (1951) : The production of showers by the coalescence of cloud droplets. Quart. J.R. Met. Soc., 77, 402-417.

Miyake, Y. (1948): The chemical nature of the saline matter in the atmosphere. Geophys. Mag., 16, 64-65.

and S. Kadokai (1961): Paper presented in the October meeting of Geochemistry Section, Chem. Soc. Japan at Akita 1961.

and Y. Sugiura (1954): The chemical studies of rain water accompanied by a typhoon. Geophys. Mag., 26, 29-34.

(1957) : Chemistry of Precipitation (in Japanese), Chijin-Shokan, Tokyo, $109 \mathrm{pp}$.

Mutoo, S. (1952) : Geochemical studies of boron. III Boron contents in rain waters. J. Chem. Soc. Japan, 73, 446-448.

Rossby, C.G. and H. Egnér (1955) : On the chemical climate and its variation with the atmospheric circulation pattern. Tellus, 7, 118-133.

Sugawara, K. (1956) : Geochemistry. Lectures on Modern Chemistry (in Japanese). IwanamiShoten, Tokyo, $94 \mathrm{pp}$.

(1959) : Synfractionation of sea salt components at the burst of bubbles. Paper presented in International Oceanographic Congress in New York 1959.

- S. Oana and T. Koyama (1949) : Separa tion of the components of atmospheric salt and their distribution. Bull. Chem. Soc. Japan, 22, 47-52.

Takahashi, Y. (1960) : On the puddles of LützowHolm Bay. Antarctic Meteorology (Proceedings of symposium held in Melbourne 1959). Pergamon Press., 321-332.

Terada, K. (1959): Distribution and circulation of iodine in atmosphere and hydrosphere. 66 pp, Ph. D. Dissertation, Nagoya University. Toba, Y. (1961) : Drop production by bursting of air bubbles on the sea surface (III). Study by use of a wind flume. Memoirs of the College of Science, Univ. of Kyoto, Ser. A, 29, 313-344. 
Twomey, S. and K.N. McMaster (1955): The production of condensation nuclei by crystallizing salt particles. Tellus, 7, 458-461.

Wilson, A.T. (1959) : Organic nitrogen in New Zealand snow. Nature, 183, 318-319. (1959): Surface of the ocean as a source of air-borne nitrogeneous material and other plant nutrients. Nature, 184, 99-101.

Woodcock, A.H. (1952): Atmospheric salt particles and raindrops. J. Met., 9, 200-212.

(1960): The origin of trade-wind orographic shower rains. Tellus, 12, 315-326.

\section{エーロゾル, 雨水, 雪が海水に比較してより重いイオンを より高い濃縮率で含むことについて}

駒林誠

(名古屋大学理学部水質科学研究室)

菅原 健（1956） とよつて得られた日本のエーロゾル，雨水，雪の無機イオン濃度の資料ともとづいて，次の事実 が見いだされた。いずれの試料の化学組成も海水と系統的な差異を有し，イオンの濃縮率の対数はそのイオンの原子 量の対数ときわめてよい增大型の直線関倸をすつ。

$\mathrm{Na}, \mathrm{Mg}, \mathrm{K}, \mathrm{Ca}, \mathrm{CO}_{3}, \mathrm{Sr}$ 特よび I はこの関係を満足する。 $\mathrm{F}, \mathrm{Fe}, \mathrm{Al}, \mathrm{SO}_{4}$ はこの関係から大きくはずれる。 $\mathrm{Cl}$ はと只の間である。

発表された観測資料によればこの関係は日本だけでなく，大西洋，ヨーロッパ沿岸，北米沿岸特よび南極大陸の沿 岸でも成り立つようと思われる。大陸内部と台風中心部の雨でこの関係が成り立たないようと思われる。

この関係を成立させるために必要な物理的機構呿よび気象条件について議論し, 熱重力拡散分離に似た同位元素分 離作用が大気と海洋の界面と䄧いてイオン濃縮を行なうことの可能性を示唆する。 